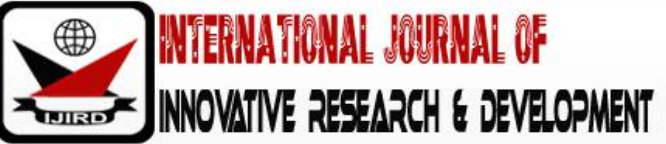

ISSN 2278 - 0211 (Online)

\section{ASEAN, the United Nations and the Security of Southeast Asia: Problems, Prospects and Paradox}

\author{
George Kwasi Agbenyegah \\ Senior Lecturer School of Development Management, \\ Ghana Christian University College, Ghana
}

\begin{abstract}
:
This article review looks at the relationship between Association of Southeast Asian Nations (ASEAN) and United Nations (UN) with respect to peace and security Southeast Asia in context of regionalism that serves as a panacea to global economic development. In addition, review ASEAN partnership and incorporation of regional security management into its institutional architecture as well as the prospects, problems and paradox therein.
\end{abstract}

Keywords: Association of Southeast Asian nations (ASEAN), United Nations (UN), regionalism, partnership and global economic development

\section{Introduction}

Regionalism remains one of the tools for economic development globally. More importantly, trade has been the bedrock of regionalism as demonstrated by the European Union (EU), one of the most successful regional organizations. However, there is also the recognition that without a benign peace and security profile economic development would hiccup. This finds expression in the incorporation of security architectures within the overarching framework of regional organizations, a manifestation of Chapter VIII of the United Nations (UN) Charter, which emphasizes the utility of regional arrangements conflict management but through pacific measures. In the post-Cold War international system, the increase in the incidence of intra-state has had the rippling effect on regionalism as regional organizations re-align their institutional motives to also cater for conflict management, and the Association of Southeast Asian Nations (ASEAN) is no exception.

It is against this backdrop that the author of the aforementioned article, underpinned by four thematic sections, provides an analysis of the extent to which ASEAN incorporates regional security management into its institutional architecture as well as the prospects, problems and paradox therein. This is in light of the fact that although ASEAN has proved to be relatively effective in undertaking its peace and security mandate, the Association is buffeted by tenuous institutions marked by what the author refers to a 'minimalist' brand of regionalism could potentially undermine conflict management within Southeast Asia. Therefore, the call by the author for institutional cooperation is predicated on the need to endow ASEAN with robust conflict management attributes which would stand the test of time.

In sub-Saharan Africa (SSA) for instance, regional organizations have had to play catch-up with conflict management although there has been minimal progress. Without a doubt, the Economic Community of West African States (ECOWAS) presents a typical case of a regional arrangement which was founded on the principles of economic values but has metamorphosed, largely, to become a conflict management mechanism. Writing on the security exigencies of a region that has witnessed intractable conflicts in states such Vietnam and Cambodia, it is apparent that the author's diagnosis of the institutional challenges within ASEAN mirrors what pertains in SSA and in that regard, the author brings to fore security challenges in Southeast Asia but with a global outlook. It would, therefore, appear that the author's recommendations for institutional cooperation between ASEAN and the UN would ameliorate significantly, the institutional dysfunctions which have riddled ASEAN. However, the author envisages that this good-intentioned cooperation would trigger a triumvirate of variables namely: Problems, Prospects, and Paradox.

\section{The ASEAN Way of Regionalism}

The problem, the author evinces, lay in the fact that ASEAN's minimalist approach to regionalism which canonizes non-intervention, an approach that emphasizes "a code of conduct based on flexible consensus, consultation, informality and sovereignty principles that has guided regional relations for four decades." The foregone problem has been accentuated in light of the demise of the Cold War, which left in its trail increasing number of intra-state conflicts and increase in the membership of ASEAN. It is within this context that the author makes a case for an overarching strategy that would have at its epicenter, a conflict prevention, management and resolution strategy. This strategy, the author argues, would complement the UN in its efforts to foster a benign security profile in Southeast Asia. However, this 
institutional complementarity between the ASEAN and the UN, according to the author, may be hampered by ASEAN's eternal commitment to the principle of non-intervention. The principle of non-intervention finds meaning in a strict adherence to a minimal approach to "regional solutions for regional problems" and proscription of "extra-regional interference in Southeast Asian affairs." The zenith of ASEAN's commitment to non-intervention, according to the author, was when during the Cold War, a period in which the international system was replete with interventions, the Association was neither neutral nor non-aligned but remained wary of any interventions within the territorial enclave of Southeast Asia, a capstone of which was the resistance to the invasion of Cambodia by Vietnam during the Third Indochina War. This, again, is paradoxical because an entity cannot vacillate between neutrality and non-alignment and claim to be averse to foreign intervention.

The author acknowledges that throughout its historical trajectory, ASEAN has resisted attempts to re-align the Association's objectives to encapsulate 'constructive intervention' and 'constructive engagement'. The author forecasts that it is unlikely that ASEAN would alter significantly, its minimalist approach to conflict management. For instance, the author is unequivocal that ASEAN was lukewarm towards the inception of 'responsibility to protect', a product of the world Outcome Summit of 2005 and a framework that provides for intervention in the internal affairs of states for purposes of peace and security as construed within framework of the UN Charter.

\section{3. beyond the ASEAN Way}

Paradoxically, however, the author provides examples that show events within ASEAN which are at variance with the much-touted non-interference pontificated by ASEAN. These examples include the constructive role played by UN envoys in resolving internal disputes in countries such as Cambodia and Myanmar. Also, member-states of ASEAN have participated in interventions in other states across the globe. It is, therefore, ironical that ASEAN is in a state of flux as a result of the Association's strict adherence to non-intervention bearing in mind the globalization of insecurity as well as in an international system where regional organizations are clamoring for powers to intervene when there is incontrovertible evidence of grisly crime, be it an internal matter.

Beyond its adherence to non-inference in the internal affairs of states, it is also obvious that ASEAN lacks the institutional and operational wherewithal to manage conflict within Southeast Asia. The author cites the inability of ASEAN to pre-empt and resolve a long-standing border disputes between Thailand and Cambodia. This explains why institutional cooperation with the UN, according to the author, must be a priority. It is through this cooperation that the author anticipates a number of prospects including a more robust approach to conflict management within ASEAN with the support of the logistical and human resource abilities of the UN, a case in point being, as mentioned already, the continuing constructive role of the UN in inducing political change in Myanmar after years of military role in that country. It is obvious that preaching non-intervention is obsolete because if the UN and the wider international community had not intervened in Myanmar through a series of sanctions and cajole, that country would still be hemorrhaging as ASEAN serenade non-interventionism. Mindful of how global powers can use interventions to pursue their parochial interests, ASEAN may not be faulted for obsessing about non-intervention. However, non-intervention in contemporary states' relations may prove futile particularly when, to restate the words of the author, "global norms, such as 'responsibility to protect' are on the rise."

\section{Conclusions}

The author concludes by cautioning that a minimalist approach to regionalism could hamper institutional cooperation between the ASEAN and UN in the area of conflict management as the Association perceives ASEAN-UN collaboration as a springboard that may metamorphose into interventionism, an anathema within ASEAN-a point the author considers paradoxically as the UN has been integral to the successes attained by ASEAN in peace and security. A corollary to the foregone is that ASEAN has no inclination to altering its policy on non-intervention and would remain averse to any arrangements which have any semblance interventionism. In this regard ASEAN may continue to remain minimalist, in the words of the author, "for the foreseeable future."

Overall, the article outlines thought-provoking perspectives. Two issues, however, must be flagged. First, the author provides relatively miniscule information on the historical evolution of ASEAN and fails to mention the exact number of member-states constituting ASEAN except to say in page 159 of the article under review that ASEAN was originally made up of five countries. For the uninitiated, it would have been useful to proceed to at least, add that the current membership stands at ten. Second, to enrich the arguments for an effectual conflict management mechanism, the author could have delineated on the nexus between governance and security. This is particularly important against the backdrop that some member-states such as Malaysia, Myanmar and Thailand have grappled with mal-governance, which threatens the security of these states. Governance, therefore, is one of the core issues whichhave implications for peace and security and should have been discussed extensively.

Notwithstanding the forgone, the author makes three strong points which resonate with contemporary issues in international politics. First, the author signals that strict adherence to non-intervention must give way to a more concerted and robust approach to conflict management, a perspective that has shaped debates over the delicate balance between states' responsibility and Westphalia principles of non-intervention and sovereignty. It is refreshing to note that notwithstanding ASEAN's unyielding commitment to non-intervention, the Association, the author states, "is open ... to the idea of sovereignty as including the element of responsibility towards their fellow Southeast Asian societies." Second, by focusing on conflict management, the author signals that economic development is intimately linked to peace and security. That is, with a deteriorating security profile, economic development cannot thrive. Third, the author reiterates the relevance of institutional complementarity between the UN and regional organizations. This must be encouraged and 
not be perceived as constituting interference. Ultimately, with an analysis through the lenses of ASEAN, the author has been highlighted issues which have global ramifications. This article is a must-read as it is imbued with nuggets on Southeast Asia's desire for a security mechanism that would resolve adequately, the security perils within the region as well as the tensions which still linger over sovereignty and responsibility.

\section{References}

i. Aboagye, F. (2007): Why is the West Pushing 'Home Grown' African peacekeeping? Training for peace programme. Seminar paper, ISS Tshwane (Pretoria).

ii. Acharya, Amitav. 2001. Creating a Security Community in Southeast Asia: ASEAN and the Problem of Regional Order. London: Routledge.

iii. Baldwin, E. Richard and Venables, J. Anthony. Regional Economic Integration, London School of Economics, 2004.

iv. Nhara, W. (1998): "Conflict Management and Peace Operations: the Role of the O.A.U. and Sub Regional Organizations". In Malan, M. (ed) Resolute partners: Building peacekeeping capacity in southern Africa. ISS Monograph series, 21 